\title{
Prediction of Mechanical and Functional Features of Aged Rubber Composites Based on BR/SBR; Structure-Properties Correlation
}

\author{
Fereshteh Motiee $^{a} * \mathbb{D}$, Tania Bigdeli ${ }^{a}$ \\ ${ }^{a}$ Department of chemistry, Islamic Azad University, Tehran North Branch, Tehran, Iran
}

Received: March 10, 2019; Revised: May 12, 2019; Accepted: October 16, 2019

\begin{abstract}
In this study, the structure-properties relationship between the thermal factors of BR/SBR blends [normalize factor $\left(\frac{\mathrm{h} B R 100}{\mathrm{hBR} 100-\mathrm{hBR}_{x}}\right)$, and the maximum peak temperature difference of thermal decomposition of BR and SBR $\left.\left(\Delta T_{\max }=T_{\max }^{B R}-T_{\max }^{S B R}\right)\right]$ with their aging time (1 to 40 days) was demonstrated using DTG profile of uncured compounds. The correlation between these two thermal factors with aging time yielded a linear equation with an acceptable correlation coefficient $(\mathrm{R} 2 \geq 0.95)$. By the obtained linear model the aging time of rubber compounds based on BR / SBR was predicted. In the second step, the curing behavior and mechanical characteristics of tire tread formulation based on BR/SBR were forecasted using the aging time of compounds, without time-consuming and costly tests. In all cases, the accuracy and reproducibility of obtained data were evaluated.
\end{abstract}

Keywords: BR/SBR, DTG profile, Aging, Properties, Structure-Properties relation.

\section{Introduction}

Investigations about the structure-properties relationship of rubber compounds based on BR / SBR is very limited. Research in this field, in order to prediction of stability of rubber compounds and their aging time, is very useful ${ }^{1}$. Motiee et.al in 2013 Investigated correlation between rheological properties of rubber compounds based on NR/ SBR with their thermal behaviors. The result showed that the rheological nature of samples had acceptable correlation with the factors obtained by thermal analysis method. In other words, a simple and reproducible experimental method was developed to efficiently predict the rheological properties of NR/SBR rubber blends ${ }^{2}$. In 2008, Taghvaei et.al demonstrated a relationship between mechanical characteristics of NR/ BR polymer hybrid in tire tread formulation with their thermal behaviors. According to TGA-DTG profiles they have stated two parameters, $\Delta \mathrm{T}_{\max }$ and peak height ratio of NR/BR blends which are correlated with rheological and mechanical properties of blends ${ }^{3}$. Yrieix et.al in 2017, showed correlations between temperature and speed process mixing of butadiene rubber / silica / silane nanocomposites with their rheological properties ${ }^{4}$. There are almost no purely theoretical expressions for the prediction of properties. Therefore, recognizing the formulation of various elastomeric compounds and investigation of the relationship between physico-mechanical properties and their thermal behavior in the tire industry is important ${ }^{5-18}$. The TG-DTG technique is used in analysis of polymer materials ${ }^{2,19}$, and some reports are presented on identification of a series of rubber compounds that indicate the high precision and acceptable accuracy of this method ${ }^{20}$. Some researchers have suggested the use of decomposition temperature to identify elastomers in cured rubber compounds with thermal analysis techniques ${ }^{20-25}$ .Some studies reported the effect of long and short-term

*e-mail: f_motiee@iau-tnb.ac.ir. aging time on the volcanized compounds ${ }^{26}$. In other studies, SBR based composites, in various conditions, was exposed to moisture and heat. By development of modern analytical methods, the effect of aging on its mechanical properties was studied ${ }^{27}$. Zhyang et al. (2012) indicates the impact of aging conditions on mechanical characteristics and thermal decomposition process of SBR-based rubber compounds ${ }^{28}$. Motiee .et al (2011) also investigated the aging Properties of uncured NR/BR blends: Using TG-DTG Technique ${ }^{29}$.

Knowing and predicting of fundamental rubber properties are really a great challenge. This research has been conducted in two phases according to DTG curves of the samples of tire treads formulation based on BR-SBR. In the first phase, the correlation between the aging times of the samples (over a period of 1 to 40 days) with two useful factors which obtained from their thermogravimetry derivative profile (DTG) was investigated. Then, by the obtained linear relations, the aging time of the compounds were predicted. In the second phase, using acceptable structure-property relationship between the aging time of the compounds with their mechanical properties, without a high cost and time consuming tests, cure behavior, tensile and abrasion properties of the rubber blends based on BR/SBR was anticipated. The accuracy and precision of the results have been statistically evaluated.

\section{Experimental Section}

\subsection{Materials}

The chemicals used in this project include: BR Cis-1220 and SBR 1502 produced by Arak Petrochemical Company, Iran, carbon black grade N-330 produced by Iran Pars Tire Co., anti-ozone IPPD manufactured by Nacil, India, antioxidant HB of Nanjing company of China, Stearic Acid as the activator by the Acid Chem company of Malaysia, 
Zinc Oxide, Normal Sulfur, CBS and TMTD Accelerator of Lanxess Co. Belgium, Aromatics Oil produced by Rhein Chem, Germany, Paraffin Wax, Iran SHIMI Co., Inc. The formulation of the rubber compounds used is based on Table 1.

Table 1. Formulation of tire tread based on BR/SBR blend

\begin{tabular}{|c|c|c|c|}
\hline Compound & & Value(Phr) & Company \\
\hline $\mathrm{BR}^{\mathrm{a}}$ & Cis- 1220 & 65 & $\begin{array}{l}\text { Arak Petrochemical, } \\
\text { Iran }\end{array}$ \\
\hline $\mathrm{SBR}^{\mathrm{b}}$ & 1502 & 35 & $\begin{array}{c}\text { Thaihua, Bangkok } \\
\text { Thailand }\end{array}$ \\
\hline $\mathrm{CB}^{\mathrm{c}}$ & N330 & 50 & Pars Tire, Iran \\
\hline $\mathrm{ZnO}^{\mathrm{d}}$ & & 48 & Shekohieh, Iran \\
\hline Stearic acid & $\begin{array}{l}\text { PLMAC } \\
1600\end{array}$ & 2.5 & Acid Chem, Malaysia \\
\hline $\mathrm{HB}$ & & 2 & Nanjing, China \\
\hline $\mathrm{IPPD}^{\mathrm{e}}$ & Pilfex 13 & 1 & Nacil, India \\
\hline Rio WAX & $\begin{array}{l}\text { Anti lux } \\
65 \mathrm{X}\end{array}$ & 1 & $\begin{array}{c}\text { Rhein Chemie, } \\
\text { Germany }\end{array}$ \\
\hline Sulfur & - & 1.5 & Tesduck, Iran \\
\hline TMTD $^{\mathrm{f}}$ & - & 0.1 & $\begin{array}{l}\text { Taizhou Huangyan } \\
\text { Donghai,China }\end{array}$ \\
\hline $\mathrm{CBS}^{\mathrm{g}}$ & - & 0.9 & $\begin{array}{l}\text { Taizhou Huangyan } \\
\text { Donghai,China }\end{array}$ \\
\hline $\mathrm{Ar}-\mathrm{Oil}^{\mathrm{h}}$ & - & 11 & IRANOL CO, Iran \\
\hline
\end{tabular}

a. Butadiene rubber; b. styrene-butadiene rubber; c. Carbon Black; d. zinc Oxide; e. N-isopropyl-N'-phenyl-p-phenylenediamine; f. Trimethyl thiuram disulfide; g. N-cyclohexyl-2-benzothiazole sulfenamide; h. Aromatic Oil.

\subsection{Sample preparation}

Rubber compounds were created based on the presented formulation in Table 1, with different aging period (1 to 40 days) in aging chamber $\left(25^{\circ} \mathrm{C}\right.$ temperature and relative humidity of $35-45 \%$ ) with the aim of obtaining aging effect on the thermal behavior, mechanical and functional properties of the specimens. A laboratory- size two roll mill with a speed of 1.2 in $6 \times 18$ inches (the right-hand side represents the diameter and the lefthand side represents the width of each rollers), was employed to prepare rubbery samples. The mixing divided in a two step process; in the first step BR and SBR was masticated about 5 minute, continued by adding carbon black, zinc oxide and other additives for about 5 minutes. The curing agent was then added for $5 \mathrm{~min}$. The temperature was set as $70-75^{\circ} \mathrm{C}$, and the compound was mixed for $5 \mathrm{~min}$. After mixing, a part of the compound was relaxed for 24 hours in an aging chamber under the mentioned conditions, prior to property assessments. Other portions of the mixture were given aging periods of 7, 14, 21, 30 and 40 days, and then their thermal behavior, rheological and mechanical properties were investigated.

\subsection{Sample characterization}

\subsubsection{Rheological properties}

The rheological features of rubber compounds were examined by the HIWA900 MDR rheometer according to
ASTM D5289 standard. Curing factors that are the result of drawing torque changes based on time include CRI, $\mathrm{TC}_{90}, \mathrm{TS}_{2}$, $\mathrm{ML}$, and $\mathrm{MH}$, which were obtained by examining the output graph of the rheometer and were recorded in Table 2. Using this table, the aging impact on each of the curing parameters can be investigated. As expected, by the increase of aging time, the curing time decreases, and curing speed increases and torque difference that is indirectly representative of the crosslink densities is reduced. Repeatability of data indicates that system changes are constant and the measurements have enough accuracy. The increase in aging time resulted in a decrease in the ML-MH difference, which is due to the decreased stiffness and hardness of the compound. By the increase of aging, the $\mathrm{TC}_{90}$ and $\mathrm{TS}_{2}$ levels have also been reduced that indicates the reduction of curing safety and reduction of the active positions in the polymer chains in rubber blends ${ }^{29}$.

Table 2. Rheological properties of BR/SBR blends aged for different days

\begin{tabular}{lccc}
\hline $\begin{array}{l}\text { Aging } \\
(\text { Day) }\end{array}$ & $\begin{array}{c}\mathbf{T S}_{\mathbf{2}}(\mathbf{S e c}) \\
( \pm \text { SD) }\end{array}$ & $\begin{array}{c}\mathbf{T C}_{\mathbf{9}}(\mathbf{S e c}) \\
( \pm \text { SD })\end{array}$ & $\begin{array}{c}\text { CRI (sec) } \\
( \pm \text { SD })\end{array}$ \\
\hline 1 & $5.4( \pm 0.02)$ & $15.0( \pm 0.8)$ & $10.1( \pm 0.2)$ \\
7 & $5.3( \pm 0.04)$ & $15.0( \pm 0.3)$ & $10.3( \pm 0.3)$ \\
14 & $5.4( \pm 0.05)$ & $14.5( \pm 0.6)$ & $10.6( \pm 0.2)$ \\
21 & $5.1( \pm 0.02)$ & $14.1( \pm 0.5)$ & $11.0( \pm 0.4)$ \\
30 & $5.0( \pm 0.6)$ & $13.5( \pm 0.4)$ & $11.7( \pm 0.3)$ \\
40 & $4.4( \pm 0.9)$ & $13.4( \pm 0.5)$ & $12.0( \pm 0.2)$ \\
\hline
\end{tabular}

\section{Mechanical Properties}

In order to investigate the mechanical properties of rubber compounds including tensile strength, elongation at break and modulus, the M350-5CX testometric was used. The device automatically repeats each test three times. The stiffness of the compounds with five times repeatability in terms of Shore A was measured with the device HP-AS manufactured by Bairss, Germany, and the fatigue test was conducted using the HIWA600 device manufactured in Iran. Table 3 presents the effect of aging on the mentioned properties.

The aging process of rubber composites are irreversible phenomenon, and are very complicated. As it can be noted by the information obtained from tensile tests, because of aging, all properties have been reduced. These changes can be explained by the fact that during the period of applying the aging three considerable phenomena occur ${ }^{30}$ :

1. Deformation in the polymeric chain, such as shrinkage, swelling and elongation.

2. Changes on the interaction of polymer chains from BR-BR and SBR-SBR to BR-SBR

3. Network formation.

The obtained results (Table 3 ) of the tensile properties of vulcanized compound based on BR / SBR indicate that due to changes in the composition of the compound by aging 
Table 3. Mechanical properties of BR/SBR rubber samples aged for different days

\begin{tabular}{lccccc}
\hline $\begin{array}{c}\text { Aging } \\
(\text { Day) }\end{array}$ & $\begin{array}{c}\text { Strain Peak }(\%) \\
( \pm \text { SD) }\end{array}$ & $\begin{array}{c}\text { Modulus 300\% } \\
( \pm \text { SD })\end{array}$ & $\begin{array}{c}\text { Modulus 100\% } \\
( \pm \text { SD })\end{array}$ & $\begin{array}{c}\text { Abrasion Resilience } \\
(\mathbf{m m})( \pm \text { SD })\end{array}$ & $\begin{array}{c}\text { Fatigue Cycle } \\
( \pm \text { SD })\end{array}$ \\
\hline 1 & $475.4( \pm 2)$ & $9.1( \pm 0.01)$ & $2.8( \pm 0.03)$ & $77.2( \pm 0.01)$ & $26105( \pm 3)$ \\
7 & $453.9( \pm 3)$ & $8.3( \pm 0.03)$ & $2.6( \pm 0.02)$ & $79.7( \pm 0.04)$ & $26010( \pm 1)$ \\
14 & $443.2( \pm 5)$ & $8.3( \pm 0.07)$ & $2.4( \pm 0.04)$ & $86.1( \pm 0.02)$ & $23582( \pm 2)$ \\
21 & $430.4( \pm 2)$ & $7.2( \pm 0.06)$ & $2.0( \pm 0.03)$ & $90.3( \pm 0.03)$ & $22227( \pm 3)$ \\
30 & $424.2( \pm 3)$ & $6.9( \pm 0.02)$ & $2.0( \pm 0.01)$ & $92.3( \pm 0.02)$ & $21584( \pm 1)$ \\
40 & $370.2( \pm 4)$ & $6.1( \pm 0.03)$ & $1.9( \pm 0.05)$ & $96.1( \pm 0.06)$ & $20062( \pm 2)$ \\
\hline
\end{tabular}

time, such as deformation of chains, reciprocal changes in chains and network formation, there will be some change in aging resistance of the compounds. As the results confirm, by increase of aging time, the tensile strength, fatigue, modulus and corrosion (abrasion) resistance decrease.

\subsection{Thermal behavior}

In order to study the thermal behavior and TG-DTG curves of uncured compound of BR / SBR, the STA-1500 device was used. A certain amount of sample was weighed and placed in a sample pan located inside a furnace with a programmable control temperature. The entire system is enclosed in a chamber so that the intended atmosphere can be controlled. After selecting the nitrogen, the suitable thermal program was adjusted and the weight loss rate was expressed in mg or percent of the original sample mass. After the evacuation of volatile component, the atmosphere was changed to air and heating continued to $650^{\circ} \mathrm{C}$. The weight loss of the sample as a function of temperature is controlled. Figure 1 illustrated the TG-DTG curves of BR/SBR rubber specimens aged for 30 days and Figure 2 shown the TG-DTG curve of $\mathrm{BR}_{100}$ aged for one day. Table 4 represents the thermal factors obtained from the TG-DTG curves of the BR / SBR aged blends.

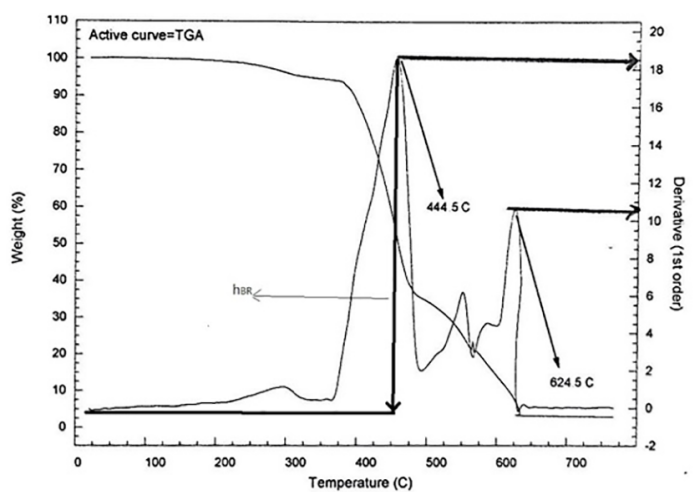

Figure 1. TG-DTG curves of BR/SBR rubber specimens aged for 30 days.

\section{Results and Discussion}

This research was conducted in two phases.

\subsection{The first phase}

In the first part, the study of the relation between the aging time of the compounds aged for 1, 7, 14, 21, 30 and 40

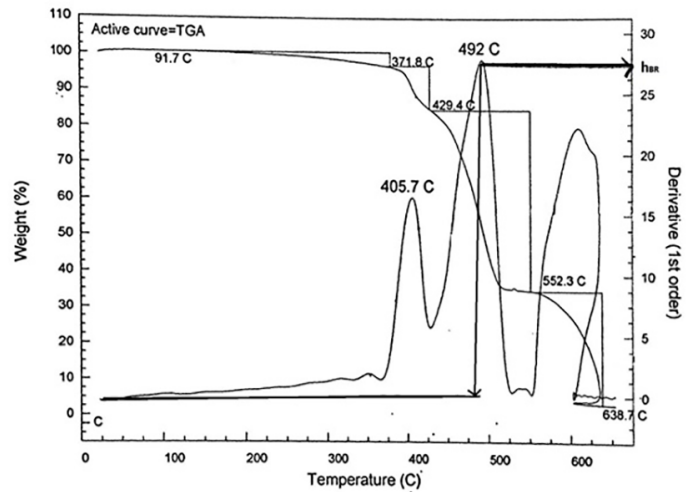

Figure 2. TG-DTG curve of BR100 aged for one day

Table 4. Thermal properties of BR/SBR rubber specimens aged for different days

\begin{tabular}{lclccc}
\hline $\begin{array}{l}\text { Aging } \\
\text { (Day) }\end{array}$ & hBR & $\frac{h B R 100}{h B R 100-h B R x}$ & $\begin{array}{c}\text { Tmax } \\
\mathbf{S B R}\left({ }^{\circ} \mathbf{C}\right) \\
( \pm \text { SD) }\end{array}$ & $\begin{array}{c}\text { Tmax } \\
\mathbf{B R}\left({ }^{\circ} \mathbf{C}\right)\end{array}$ & $\begin{array}{c}\text { Tmax } \\
( \pm \mathbf{S D})\end{array}$ \\
\hline 1 & 20.5 & 2.93 & 600.4 & 444.4 & $156( \pm 2)$ \\
7 & 20.0 & 2.66 & 616.0 & 451.0 & $165( \pm 1)$ \\
14 & 19.8 & 2.57 & 620.8 & 452.8 & $168( \pm 1.5)$ \\
21 & 19.5 & 2.44 & 635.3 & 459.3 & $176( \pm 1.55)$ \\
30 & 18.5 & 2.06 & 624.5 & 444.5 & $180( \pm 1.53)$ \\
40 & 18.2 & 1.98 & 636.7 & 452.7 & $184( \pm 1.7)$ \\
\hline
\end{tabular}

hBR100 aged for 1 day= 27.5 (Fig.2)

days with the factors determined from their thermal behavior, including Normalyze Factor and $\Delta \mathrm{T}_{\max }$ were considered to find an acceptable relationship between these parameters (Equation 1,2). With respect to the linear equation and correlation coefficient, their relation is discussed. As shown in Figures 3-4, the correlation between $\mathrm{T}_{\max \Delta}$ and Normalyze Factor with aging time of composites based on BR / SBR yielded a linear equation with $\mathrm{R}^{2}=0.95$ and 0.97 . This comes close to suggest a correlation between aging times of blends to their thermal behavior.

$$
\begin{aligned}
& \mathrm{Y}=\mathrm{f}(\mathrm{X}) \\
& \text { Aging time }=\mathrm{f}(\Delta T \max )
\end{aligned}
$$

$$
\mathrm{Y}=\mathrm{f}(\mathrm{X})
$$

Aging time $=\mathrm{f}($ Normalyze Factor $)$ 


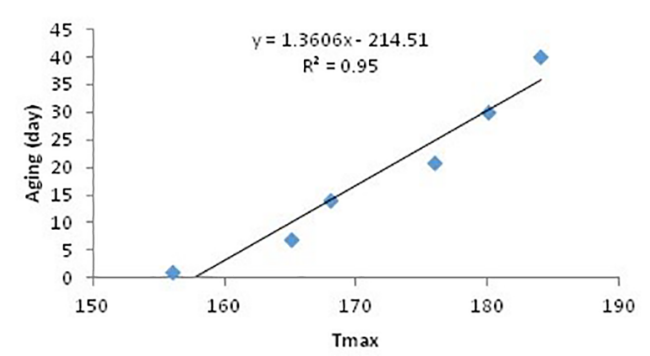

Figure 3. Aging time vs. $\Delta \mathrm{Tmax}\left({ }^{\circ} \mathrm{C}\right)$

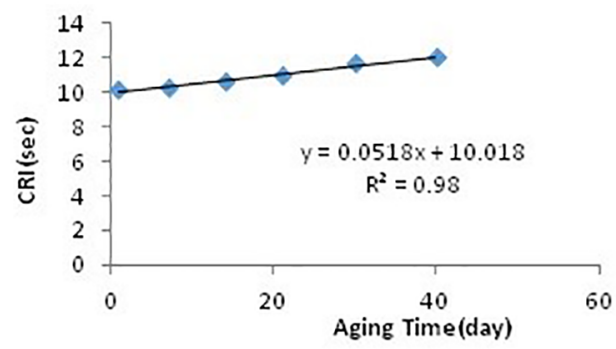

Figure 4. Aging time vs. Normalyze Factor

For techniques that analyze a process or a method, the assessment is based on the calculation of the relative error and is as follows ${ }^{30}$.

$$
\% \Delta=\frac{\text { Experimental Result }- \text { Calculated Result }}{\text { Experimental Result }} \times 100
$$

- If the relative error is lower than $10 \%$, the correlation is acceptable.

- If the error is between $10 \%$ and $30 \%$, depending on the importance of the process, it possibly will be acceptable.

- If the error is more than $30 \%$, the method is unacceptable.

Considering the achieved correlation coefficient from the calibration curve (Fig. 3-4) and the reported relative error $(\% \Delta)$ between the real aging time with calculated data for the compounds (Table 5,6), it is suggested that the defined correlation is an acceptable method for predicting the aging period of rubber composites based on BR / SBR using thermal indexes obtained from their thermal analysis curve.

Table 5. Comparison between real aging time and predicted ones by TGA factor

\begin{tabular}{lccc}
\hline$\left.\Delta \operatorname{Tmax}^{(}{ }^{\circ} \mathbf{C}\right)$ & $\begin{array}{c}\text { Aging } \\
\text { (Day) real }\end{array}$ & $\begin{array}{c}\text { Aging (Day) } \\
\text { Calculated }^{\mathbf{a}}\end{array}$ & $\% \mathbf{~} \boldsymbol{\Delta}$ \\
\hline 156 & 1 & 2.3 & 3.3 \\
165 & 7 & 9.9 & 0.41 \\
168 & 14 & 13.9 & 0.007 \\
176 & 21 & 24.8 & 0.18 \\
180 & 30 & 30.3 & 0.01 \\
184 & 40 & 35.7 & 0.10 \\
\hline
\end{tabular}

${ }^{a}$ Cure Fitting equation : Aging $=1.360 \mathrm{x}-214.5 \quad \mathrm{R}^{2}=0.950$

Where $\mathrm{x}=\Delta \mathrm{Tmax}$
Table 6. Comparison between real aging time and predicted ones by TGA factor

\begin{tabular}{lccc}
\hline $\begin{array}{l}\text { Normalyze } \\
\text { Factor }\end{array}$ & $\begin{array}{c}\text { Aging (Day) } \\
\text { real }\end{array}$ & $\begin{array}{c}\text { Aging (Day) } \\
\text { Calculated }\end{array}$ & $\mathbf{\% ~} \boldsymbol{\Delta}$ \\
\hline 2.93 & 1 & 0.39 & 1.39 \\
2.66 & 7 & 10 & 0.42 \\
2.57 & 14 & 13.7 & 0.02 \\
2.44 & 21 & 18.8 & 0.10 \\
2.06 & 30 & 33.7 & 0.12 \\
1.98 & 40 & 36.88 & 0.08 \\
\hline a Cure Fitting equation : Aging=-39.235x+114.57 & $\mathrm{R}^{2}=0.97$ \\
Where x= Normalyze Factor based on BR base line &
\end{tabular}

\subsection{The second phase}

1 - In this section, using the aging time of the samples, the rheological properties of composites based on BR / SBR were predicted. These can be expressed as follows:

$$
\begin{aligned}
& \mathrm{Y}=\mathrm{f}(\mathrm{X}) \\
& \text { Rheological properties }=\mathrm{f}(\text { Aging time })
\end{aligned}
$$

The linear correlation with $\mathrm{R}^{2}=0.98$ and $\mathrm{R}^{2}=0.94$ was obtained by drawing of rheological indexes $\left(\mathrm{CRI}-\mathrm{TC}_{90}\right)$ of rubbery materials against aging time of compounds (Figures 5 and 6).

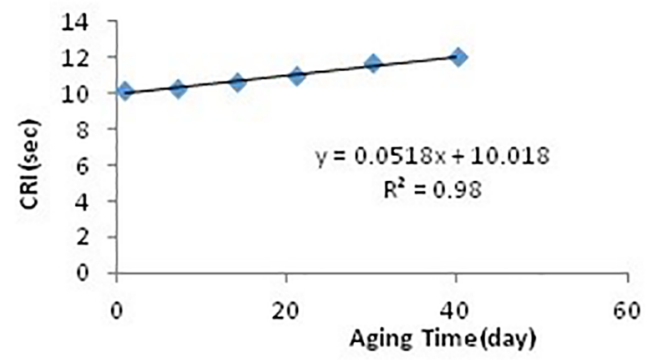

Figure 5. CRI vs. Aging time

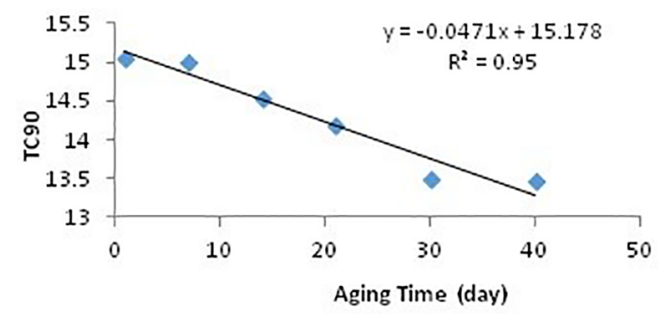

Figure 6. $\mathrm{TC}_{90}$ vs. Aging time

In order to investigate the relative error of experimental and calculated values, $\Delta \%$ was measured. Considering the obtained correlation coefficients from the calibration curve (Figures 5 and 6) and the reported $\% \Delta$ between the experimental and calculated results for the rheological properties of the compounds (Table 7), it is suggested that the defined connection is an acceptable method to predict the curing behavior of rubber composites based on BR / SBR without spending too much and conducting time-consuming and costly tests. 
Table 7. Experimental and calculated rheological properties of composites based on BR / SBR blends.

\begin{tabular}{lcccccc}
\hline Aging & $\begin{array}{c}\text { CRI[Min;sec] } \\
\text { Measured }\end{array}$ & $\begin{array}{c}\text { CRI[Min;sec] } \\
\text { Calculated }^{\mathbf{a}}\end{array}$ & $\mathbf{\% \Delta}$ & $\begin{array}{c}\mathbf{T C}_{\mathbf{9 0}}[\mathbf{M i n} ; \mathbf{s e c}] \\
\text { Measured }^{-}\end{array}$ & $\begin{array}{c}\mathbf{T C}_{\mathbf{9 0}}[\mathbf{M i n} ; \mathbf{s e c}] \\
\text { Calculated }^{\mathbf{b}}\end{array}$ & $\mathbf{\% \Delta}$ \\
\hline 1 & 10.1 & 10.0 & 0.009 & 15.0 & 14.4 & 0.04 \\
7 & 10.3 & 10.3 & 0.0 & 15.0 & 14.4 & 0.04 \\
14 & 10.6 & 10.7 & 0.009 & 14.5 & 14.4 & 0.006 \\
21 & 11.0 & 11.1 & 0.009 & 14.1 & 14.5 & 0.02 \\
30 & 11.7 & 11.5 & 0.01 & 13.5 & 14.5 & 0.07 \\
40 & 12.0 & 12.0 & 0.0 & 13.4 & 14.5 & 0.08 \\
\hline
\end{tabular}

${ }^{a}$ Cure Fitting equation : $\mathrm{CRI}=0.0518 \mathrm{x}+10.018$

${ }^{\mathrm{b}}$ Cure Fitting equation : $\mathrm{TC}_{90}=-0.0471 \mathrm{x}+15.178$

2 - In this section, the connection between the mechanical or functional properties of the vulcanized compounds based on BR / SBR matrix with the aging time of the samples is investigated. These can be expressed as follows:

$$
\begin{aligned}
& \mathrm{Y}=\mathrm{f}(\mathrm{X}) \\
& \text { Tensile properties }=\mathrm{f}(\text { Aging time })
\end{aligned}
$$

The relation between the mechanical properties of aged compounds including tensile strength, modulus 100 , fatigue and abrasion resistance in terms of aging time of the samples were obtained as a first-order linear equation with correlation coefficients of $0.93,0.97,0.95$ and 0.95 , respectively.

Considering the obtained correlation coefficients from the Figure 7-10 and the $\% \Delta$ value determined between the experimental and calculated (Table 8 ), it can be concluded that using the aging time of rubber blends based on BR / SBR formulation, it is likely that properties can be predicted without costly and time-consuming tests, and possibly through cost management, it can be an effective step to reduce the financial burden of production.

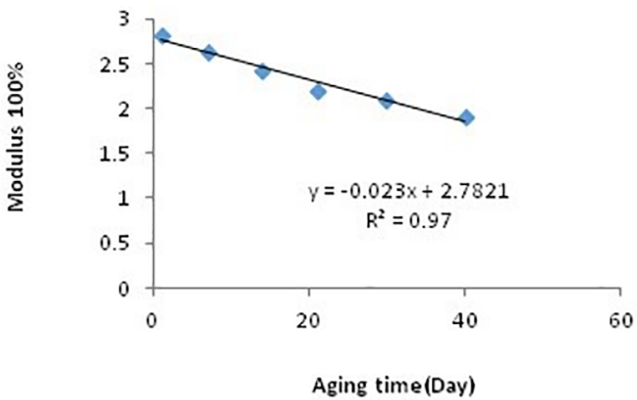

Figure 7. Stress Peak vs. Aging time

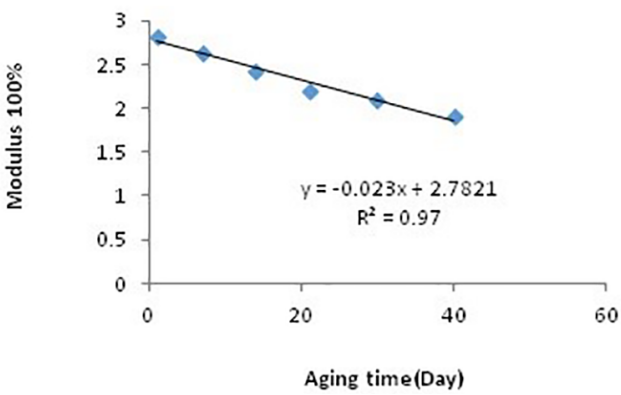

Figure 8. Modulus $100 \%$ vs. Aging time

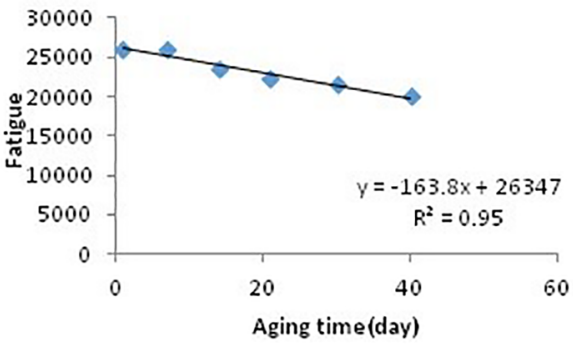

Figure 9. Fatigue vs. Aging time

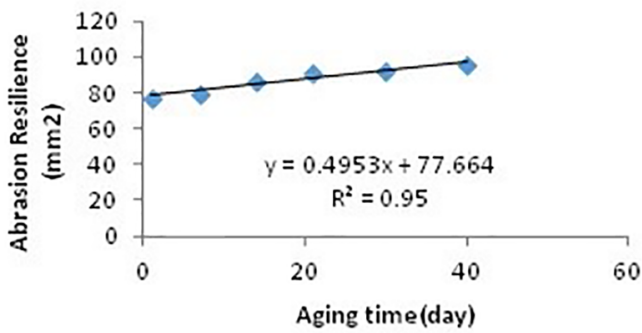

Figure 10. Abrasion resilience vs. Aging time

In order to case study and look into the accuracy of the obtained relationships, similar studies were applied to investigate the performance properties of BR / SBR rubbery materials aged for 7, 21 and 30 days. The values of CRI, $\mathrm{TC}_{90}$, stress, modulus $100 \%$, fatigue and abrasion were measured and compared with the data extracted from the obtained linear equation (Fig 7-10). The values obtained experimentally for specimens are tabulated in Tables 9 and 10.

Statistical analysis was performed on the results presented in Table 9 and 10 demonstrate that the linear correlation coefficient of Pearson ( $p$ ) between experimental and calculated values of $\mathrm{TC}_{90}, \mathrm{CRI}$, stress, abrasion of samples is obtained $0.988,990.992,0.0$ and 0.999 , respectively, It means that the zero hypothesis $(\mathrm{H}: \mathrm{p}=0)$, which means no correlation at the significance level of 0.05 , can be rejected. On the other hand, the significance level of the test in all three cases was respectively $0.50,0.42,0.46$, and 0.017 (smaller than 0.05 ), and confirmed that the zero hypothesis $(\mathrm{H}: \mathrm{p}=0)$ at 0.05 level can be rejected. On the other hand there is a desirable correlation between the aging time with rheological properties and mechanical nature of tire tread formulation based on BR / SBR and there is no significant difference between the experimental and predicted data; (Tables 11-14) and (Figures 11-14). 
Table 8. Experimental and calculated mechanical properties of composites based on BR / SBR blends

\begin{tabular}{|c|c|c|c|c|c|c|c|c|c|c|c|c|}
\hline Aging & $\begin{array}{c}\text { Stress } \\
\text { Peak(N/ } \\
\left.\text { mm² }^{2}\right) \\
\text { Measured }\end{array}$ & $\begin{array}{c}\text { Stress } \\
\text { Peak(N/ } \\
\left.\text { mm }^{2}\right)\end{array}$ & $\% \Delta$ & $\begin{array}{c}\text { Modulus } \\
100 \% \\
\text { Measured }\end{array}$ & $\begin{array}{c}\text { Modulus } \\
100 \%\end{array}$ & $\begin{array}{c}\% \\
\Delta\end{array}$ & $\begin{array}{c}\text { Fatigue } \\
\text { (Cycle) } \\
\text { Measured }\end{array}$ & $\begin{array}{l}\text { Fatigue } \\
\text { (Cycle) }\end{array}$ & $\% \Delta$ & $\begin{array}{c}\text { Abrasion } \\
\text { Resilience } \\
\left(\mathbf{m m}^{2}\right) \\
\text { Measured }\end{array}$ & $\begin{array}{c}\text { Abrasion } \\
\text { Resilience } \\
\left(\mathbf{m m}^{2}\right)\end{array}$ & $\% \Delta$ \\
\hline & & Calculated $^{\mathrm{a}}$ & & & Calculated $^{\mathrm{b}}$ & & & Calculated & & & Calculated $^{\mathrm{d}}$ & \\
\hline 1 & 12.2 & 12.1 & 0.008 & 2.8 & 2.5 & 0.1 & 26105 & 26183.2 & 0.002 & 77.2 & 78.1 & 0.01 \\
\hline 7 & 11.6 & 11.8 & 0.010 & 2.6 & 2.6 & 0.0 & 26010 & 25200 & 0.03 & 79.7 & 81.1 & 0.01 \\
\hline 14 & 11.6 & 11.6 & 0.00 & 2.4 & 2.4 & 0.0 & 23582 & 24053.8 & 0.02 & 86.1 & 84.5 & .01 \\
\hline 21 & 11.4 & 11.4 & 0.00 & 2.0 & 2.2 & 0.1 & 22227 & 22907.2 & 0.03 & 90.3 & 88.0 & 0.02 \\
\hline 30 & 10.9 & 11.0 & 0.009 & 2.0 & 2.0 & 0.0 & 21584 & 21433 & 0.006 & 92.3 & 92.5 & 0.002 \\
\hline 40 & 10.8 & 10.7 & 0.009 & 1.9 & 1.8 & 0.5 & 20062 & 19795 & 0.01 & 96.1 & 97.4 & 0.01 \\
\hline
\end{tabular}

${ }^{\text {a }}$ Cure Fitting equation : Stress Peak $=-0.0352 \mathrm{x}+12.141$

$$
\begin{aligned}
& \mathrm{R}^{2}=0.926 \\
& \mathrm{R}^{2}=0.969 \\
& \mathrm{R}^{2}=0.951 \\
& \mathrm{R}^{2}=0.953
\end{aligned}
$$

Where $x=$ Aging
Where $x=$ Aging
Where $x=$ Aging
Where $x=$ Aging

\begin{tabular}{|c|c|c|c|c|c|c|}
\hline $\begin{array}{l}\text { Aging } \\
\text { (Day) }\end{array}$ & $\begin{array}{l}\mathrm{TC}_{90}(\mathrm{~min}) \\
\text { Measured }\end{array}$ & $\begin{array}{l}\mathrm{TC}_{90}(\mathrm{~min}) \\
\text { calculated }\end{array}$ & $\% \Delta$ & $\begin{array}{c}\text { CRI } \\
\text { Measured }\end{array}$ & $\begin{array}{c}\text { CRI } \\
\text { calculated }\end{array}$ & $\% \Delta$ \\
\hline 7 & 14.36 & 14.4 & 0.002 & 10.15 & 10.3 & 0.014 \\
\hline 21 & 14.38 & 14.4 & 0.001 & 10.95 & 11.1 & 0.013 \\
\hline 30 & 14.48 & 14.5 & 0.001 & 11.6 & 11.5 & 0.008 \\
\hline
\end{tabular}

${ }^{c}$ Cure Fitting equation : Fatigue $=-163.8 x+26347$

${ }^{\mathrm{d}}$ Cure Fitting equation : Abrasion Resilience $=0.495 \mathrm{x}+77.66$

\begin{tabular}{|c|c|c|c|c|c|c|c|c|c|}
\hline $\begin{array}{l}\text { Aging } \\
\text { (Day) }\end{array}$ & $\begin{array}{l}\text { Stress Peak } \\
\left(\mathbf{N} / \mathbf{m m}^{2}\right) \\
\text { Measured }\end{array}$ & $\begin{array}{l}\text { Stress Peak } \\
\left(\mathrm{N} / \mathbf{m m}^{2}\right) \\
\text { calculated }\end{array}$ & $\% \Delta$ & $\begin{array}{l}\text { Fatigue } \\
\text { (Cycle) } \\
\text { Measured }\end{array}$ & $\begin{array}{l}\text { Fatigue } \\
\text { (Cycle) } \\
\text { calculated }\end{array}$ & $\% \Delta$ & $\begin{array}{l}\text { Abrasion } \\
\text { Resilience } \\
\left(\mathbf{m m}^{2}\right) \\
\text { Measured }\end{array}$ & $\begin{array}{l}\text { Abrasion } \\
\text { Resilience } \\
\left(\mathrm{mm}^{2}\right) \\
\text { calculated }\end{array}$ & $\% \Delta$ \\
\hline 7 & 11.0 & 11.8 & 0.07 & 25186 & 25200 & $\sim 0.0$ & 81.0 & 81.1 & $\sim 0.0$ \\
\hline 21 & 11.30 & 11.4 & 0.008 & 22900 & 22907.2 & $\sim 0.0$ & 87.9 & 88.0 & 0.001 \\
\hline 30 & 11.80 & 11.0 & 0.06 & 31395 & 21433 & 0.3 & 92.0 & 92.5 & 0.005 \\
\hline
\end{tabular}

Table 9. Comparison of measured and calculated data of $\mathrm{TC}_{90}$ and CRI

Table 10. Comparison of measured and calculated data of Stress, Fatigue and Abrasion.

Table 11. Statistical results of comparison of experimental and calculated $\mathrm{TC}_{90}$ using aging times

\begin{tabular}{lccc}
\hline & & $\begin{array}{c}\mathbf{T C}_{\mathbf{9 0}} \\
\text { Calculated }\end{array}$ & $\begin{array}{c}\mathbf{T C}_{\mathbf{9 0}} \\
\text { Measured }\end{array}$ \\
\hline & $\begin{array}{c}\text { Pearson } \\
\text { Correlation }\end{array}$ & 1 & $.988^{*}$ \\
$\mathrm{TC}_{90}$ & Sig. (1-tailed) & & .050 \\
& $\mathrm{~N}$ & 3 & 3 \\
\hline & $\begin{array}{c}\text { Pearson } \\
\text { Correlation }\end{array}$ & $.988^{*}$ & 1 \\
$\mathrm{TC}_{90}$ & $\begin{array}{c}\text { Measured } \\
\text { Sig. (1-tailed) }\end{array}$ & .050 & \\
& $\mathrm{~N}$ & 3 & 3 \\
\hline
\end{tabular}

\begin{tabular}{|c|c|c|c|}
\hline & & $\begin{array}{c}\text { CRI } \\
\text { Calculated }\end{array}$ & $\begin{array}{c}\text { CRI } \\
\text { Measured }\end{array}$ \\
\hline \multirow{3}{*}{$\begin{array}{l}\text { CRI } \\
\text { Calculated }\end{array}$} & $\begin{array}{l}\text { Pearson } \\
\text { Correlation }\end{array}$ & 1 & $.992 *$ \\
\hline & Sig. (1-tailed) & & .042 \\
\hline & $\mathrm{N}$ & 3 & 3 \\
\hline \multirow{3}{*}{$\begin{array}{l}\text { CRI } \\
\text { Measured }\end{array}$} & $\begin{array}{c}\text { Pearson } \\
\text { Correlation }\end{array}$ & $.992 *$ & 1 \\
\hline & Sig. (1-tailed) & .042 & \\
\hline & $\mathrm{N}$ & 3 & 3 \\
\hline
\end{tabular}

*. Correlation is significant at the 0.05 level (1-tailed).
Table 12. Statistical results of comparison of experimental and calculated CRI using aging times.

*. Correlation is significant at the 0.05 level (1-tailed). 
Table 13. Statistical results of comparison of experimental and calculated stress using aging times.

\begin{tabular}{lccc}
\hline & & $\begin{array}{c}\text { Stress } \\
\text { Calculated }\end{array}$ & $\begin{array}{c}\text { Stress } \\
\text { Measured }\end{array}$ \\
\hline Stress & Pearson Correlation & 1 & $-.990^{*}$ \\
Calculated & Sig. (1-tailed) & & .046 \\
& $\mathrm{~N}$ & 3 & 3 \\
\hline \multirow{2}{*}{ Stress } & Pearson Correlation & $-.990^{*}$ & 1 \\
Measured & Sig. (1-tailed) & .046 & \\
& $\mathrm{~N}$ & 3 & 3 \\
\hline
\end{tabular}

*. Correlation is significant at the 0.05 level (1-tailed).

Table 14. Statistical results of comparison of experimental and calculated abrasion using aging times

\begin{tabular}{lccc}
\hline & & $\begin{array}{c}\text { Abrasion } \\
\text { Calculated }\end{array}$ & $\begin{array}{c}\text { Abrasion } \\
\text { Measured }\end{array}$ \\
\hline Abrasion & Pearson Correlation & 1 & $.999^{*}$ \\
Calculated & Sig. (1-tailed) & & .017 \\
& $\mathrm{~N}$ & 3 & 3 \\
Abrasion & Pearson Correlation & $.999 *$ & 1 \\
Measured & Sig. (1-tailed) & .017 & \\
& $\mathrm{~N}$ & 3 & 3 \\
*. Correlation is significant at the 0.05 level (1-tailed).
\end{tabular}

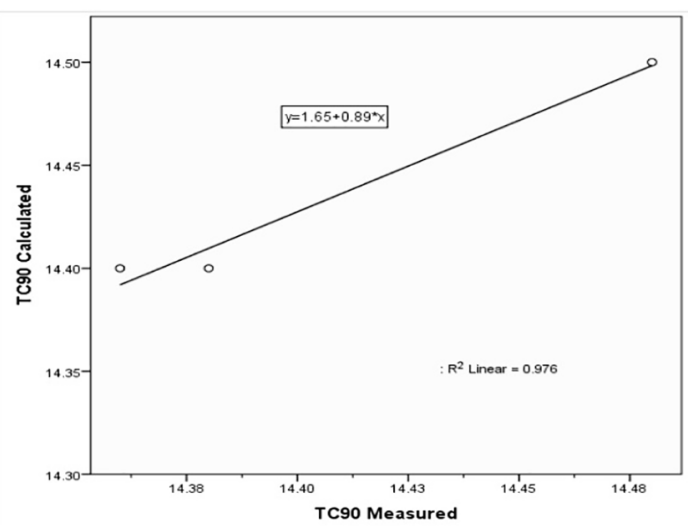

Figure 11. $\mathrm{TC}_{90}$ vs. $\mathrm{TC}_{90}$ Measured

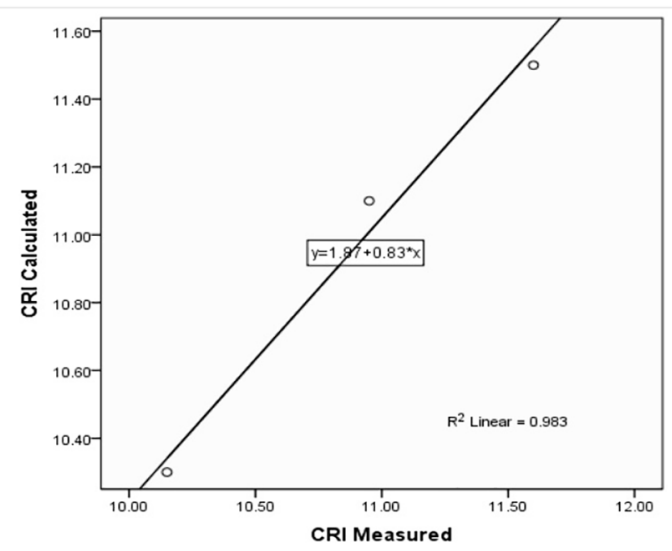

Figure 12. CRI vs. CRI Measured

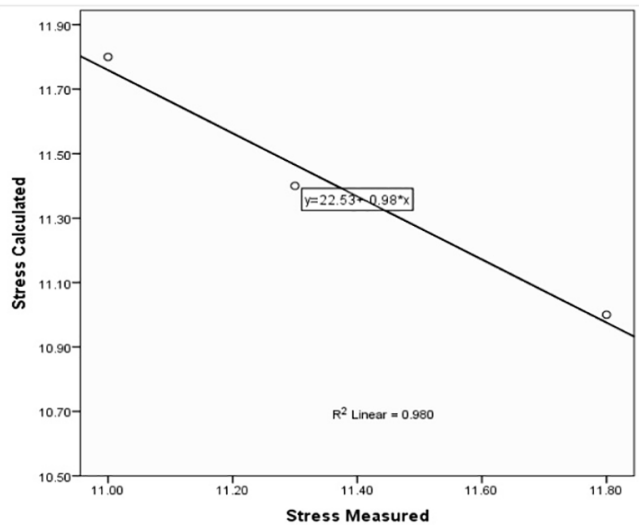

Figure 13. Stress vs. Stress Measured

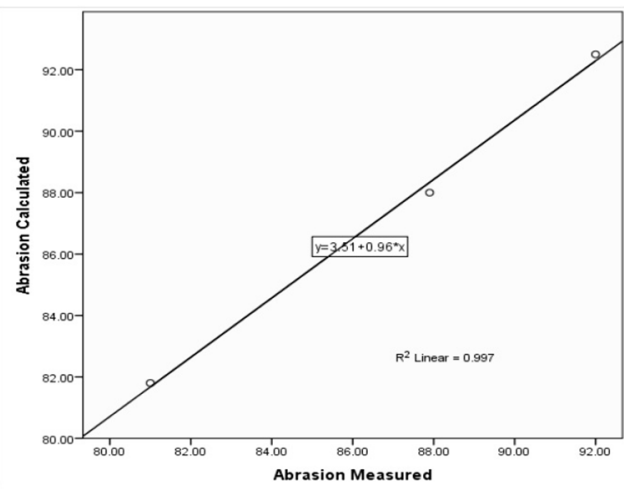

Figure 14. Abrasion vs. Abrasion Measured

\section{Conclusion}

Thermogravimetry (TG) is one of the most powerful techniques of thermal analysis that is widely used for quantitative and qualitative measurements of the components of vulcanized rubber compounds. In this study all components of BR / SBR composites was kept constant and aging was carried out in an aging box at room temperature and constant humidity $\left(25^{\circ} \mathrm{C}, 35 \%\right.$ $-45 \%)$ for different time.

1. The aging period is effective on the performance nature of BR / SBR compound (35/65). Due to the sufficient relation between the aging time with the thermal indexes $\left(\Delta \mathrm{T}_{\max }\right.$ and NF) obtained from the thermal behavior of the aged samples, it is possible to predict the aging time of these compounds. It can be pointed out, that thermal analysis presents the advantages of being a straightforward and fast method to predict the time of aging of rubbery materials.

2-As the results showed, based on satisfactory correlation between the aging times of the compounds to their thermal properties, an acceptable structure-properties correlation between the aging time with functional properties, the curing behavior, and the mechanical properties of the compounds became possible. The relationship between aging time of blends with their rheological and mechanical properties were fitted to a linear equation. 


\section{References}

1. He S, Bai F, Liu S, Ma H, Hu J, Chen L, et al. Aging properties of styrene-butadiene rubber nanocomposites filled with carbon black and rectorite. Polymer Testing. 2017;64:92-100.

2. Motiee F, Taghvaei-Ganjali S, Malekzadeh M. Investigation of correlation between rheological properties of rubber compounds based on natural rubber/styrene-butadiene rubber with their thermal behaviors. International Journal of Industrial Chemistry (IJIC). 2013;4(16):1-8.

3. Taghvaei-Ganjali S, Motiee F, Fotoohi F. Correlation between physico-mechanical properties of NR-BR blends in tire tread formulation with their thermal behaviors. Rubber Chemistry and Technology. 2008;81(2):297-316.

4. Xu X, Yu J, Xue L, Zhang C, Zha Y, Gu Y. Investigation of molecular structure and thermal properties of thermo-oxidative aged SBS in blends and their relations. Materials (Basel). 2017;10(7):e768-779.

5. George SC, Ninan KN, Groeninckx G, Thomas S. Styrenebutadiene rubber/natural rubber blends: morphology, transport behavior, and dynamic mechanical and mechanical properties. Journal of Applied Polymer Science. 2000;78(6):1280-1303.

6. Findik F, Yilmaz R, Köksal T. Investigation of mechanical and physical properties of several industrial rubbers. Materials and Design. 2004;25(4):269-276.

7. Akinlabi AK, Okieimen FE, Egharevba F, Malomo D. Investigation of the effect of mixing schemes on rheological and physico-mechanical properties of modified natural rubber blends. Materials and Design. 2006;27(9):783-788.

8. Osabohien E, Egboh SHO. Cure characteristics and physicomechanical properties of natural rubber filled with the seed shells of cherry (Chrysophyllum albidum). Journal of Applied Sciences and Environmental Management. 2007;11(2):43-48.

9. Salimi D, Nourikhorasani SN, Abdchi MR, Veshare SJ. Optimization of physico-mechanical properties of silica-filled NR/SBR compounds. Advances in Polymer Technology. 2009;28(4):224-232.

10. Ogbeifun DE, Iyasele JU, Okieimen FE. Physico-mecanical properties of natural rubber vulcanizates filled with carbonised agricultural residues. Journal of Natural Sciences Engineering and Technology. 2010;9(2):76-83.

11. El-Nemr KHF. Effect of different curing systems on the mechanical and physico-chemical properties of acrylonitrile butadiene rubber vulcanizates. Materials and Design. 2011;32(6):3361-3369.

12. Simchareon $\mathrm{W}$, Amnuaikit $\mathrm{T}$, Boonme $\mathrm{P}$, Taweepreda W, Pichayakorn W. Characterization of natural rubber latex film containing various enhancers. Procedia Chemistry. 2012;4:308-312.

13. Mohamad N, Zainol NB, Rahim F, Maulod HEA, Rahim TA, Shamsuri SR, et al. Mechanical and morphological properties of polypropylene/epoxidized natural rubber blends at various mixing ratio. Procedia Engineering. 2013;68:439-445.

14. Cao XW, Luo J, Cao Y, Yin XC, He GJ, Peng XF, et al. Structure and properties of deeply oxidized waster rubber crumb through long time ozonization. Polymer Degradation and Stability. 2014;109:1-6.
15. Mangili I, Lasagni M, Anzano M, Collina E, Tatangelo V, Franzetti A, et al. Mechanical and rheological properties of natural rubber compounds containing devulcanized ground tire rubber from several methods. Polymer Degradation and Stability. 2015;121:369-377.

16. Ahmad HS, Ismail H, Rashid AA. Tensile properties and morphology of epoxidized natural rubber/recycled acrylonitrilebutadiene rubber (ENR 50/NBRr) blends. Procedia Chemistry. 2016;19:359-365.

17. Formela K, Wołosiak M, Klein M, Wang S. Characterization of volatile compounds, structural, thermal and physicomechanical properties of cross-linked polyethylene foams degraded thermo-mechanically at variable times. Polymer Degradation and Stability. 2016;134:383-393.

18. Pajtášová $M$, Mičicová Z, Ondrušová $D$, Pecušová $B$, Feriancová A, Raník L, et al. Study of properties of fillers based on natural bentonite and their effect on the rubber compounds. Procedia Engineering. 2017;177:470-475.

19. Datta S, Antos J, Stocek R. Characterisation of ground tyre rubber by using combination of FT-IR numerical parameter and DTG analysis to determine the composition of ternary rubber blend. Polymer Testing. 2017;59:308-315.

20. Varkey JT, Augustine S, Thomas S. Thermal degradation of natural rubber/styrene butadiene rubber latex blends by thermo gravimetric method. Polymer-Plastics Technology and Engineering. 2000;39(3):415-435.

21. Xue X, Yin Q, Jia H, Zhang X, Wen Y, Ji Q, et al. Enhancing mechanical and thermal properties of styrene-butadiene rubber/carboxylated acrylonitrile butadiene rubber blend by the usage of graphene oxide with diverse oxidation degrees. Applied Surface Science. 2017;423:584-591.

22. Scuracchio CH, Waki DA, Silva MLCP. Thermal analysis of ground tire rubber devulcanized by microwaves. The Journal of Thermal Analysis and Calorimetry. 2007;87(3):893-897.

23. Song $\mathrm{P}, \mathrm{Wu} \mathrm{X}$, Wang $\mathrm{S}$. Effect of styrene butadiene rubber on the light pyrolysis of the natural rubber. Polymer Degradation and Stability. 2018;147:168-176.

24. Liu X, Bian L, Gao Y, Wang Z. Influence of ultrafine fullvulcanized powdered rubber on NR/SBR blends. Polymer Bulletin. 2012;69:747-756.

25. Hassan MM, El-Megeed AAA, Maziad NA. Evaluation of curing and physical properties of NR/SBR blends using radiation-grafting copolymer. Polymer Composites. 2009;30(6):743-750.

26. Choi SS, Kim JC, Lee SG, Joo YL. Influence of the cure systems on long time thermal aging behaviors of NR composites. Macromolecular Research. 2008;16(6):561-566.

27. Lima P, Silva SPM, Oliveira J, Costa V. Rheological properties of ground tyre rubber based thermoplastic elastomeric blends. Polymer Testing. 2015;45:58-67.

28. Xiang K, Wang X, Huang G, Zheng J, Huang J, Li G. Thermal ageing behavior of styrene butadiene random copolymer: a study on the ageing mechanism and relaxation properties. Polymer Degradation and Stability. 2012;97(9):1704-1715. 
29. Taghvaei-Ganjali S, Motiee F. A study of aging properties of uncured NR/BR blends: using TG-DTG Technique. The International Journal of Industrial Chemistry (IJIC). 2011;2(4):201-208.
30. Chandra A, Roy B, Mohamed P. Proceedings of the Tire Technology International Conference. Apollo Tires Ltd, India: R\&D Center. 2004:10-14. 